aragonite increases downwards from less than $1: 1$ at $15 \mathrm{~cm}$ to approximately $2: 1$ at $20 \mathrm{~cm}$.

The anhydrite is clearly an evaporitic component, but the vertical distribution and mutual relationships of the dolomite and aragonite suggest that the dolomite is an early diagenetic replacement of aragonite. Although wind-blown grains are seattered throughout the length of the core, there is nothing to suggest that the dolomite is detrital. All the available evidence indicates that it was formed in situ and is chemical in origin.

Owing to the extremely low annual rainfall, the pore fluids in the sabkha are supplied by the high salinity sea water of the adjacent lagoons. The waters of the tidal lagoons are alkaline with $p H$ values up to $8 \cdot 0$. In the sabkha, which extends inland for 7 miles near Abu Dhabi, the ground-water is acid with the $p \mathrm{H}$ varying between $6 \cdot 0$ and 6.2. Transitional $p \mathrm{H}$ values are found in a narrow zone along the seaward margin of the sabkha. During October 1962 the ground water-level in the sabkha stood at approximately $75 \mathrm{~cm}$ below the surface, although it varied slightly from place to place. The ground water temperature averaged $35^{\circ}$ C. A lateral and vertical migration of these fluids within the sediment is caused by ovaporation from the sabkha surface. It is thought that the pore fluids, probably rich in magnesium, bring about the transformation of aragonite to dolomite. However, until a more detailed field and laboratory study has been completed this conclusion can only be a tentative one.

The mineral identifications were made by the X-ray diffraction powder method. The dolomite consistently showed an absence of the superstructure reflexions (221) and $(11 \overline{1})$. This feature is characteristic of protodolomites ${ }^{2}$. The dolomite identified by Wells is rich in calcium $\left(\mathrm{Ca}_{54} \mathrm{Mg}_{46}\right)$ and has an expanded lattice which suggests that it may also be a protodolomite, although Wells did not record the absence of the superstructure reflexions.

It is of interest at this stage of the investigations, that the dolomite is associated in the Qatar region with gypsum and at Abu Dhabi with anhydrite, in what at first sight appear to be similar environments.

Recent work on a series of short cores taken across the seven mile width of the sabkha near Abu Dhabi has revealed the presence of abundant gypsum. A complex. and as yet not understood, series of relationships exists between the gypsum and the anhydrite. The results of these later investigations will be more fully described olsewhere.

This communication is based on work forming part of a programme of research on the Recent sediments of the Trueial Coast, Persian Gulf, financed by the Department of Scientific and Industrial Research.
R. Curtis
G. Evans
D. J. J. Kinsman
D. J. Shearman

Department of Geology,

Imperial College of Science and Technology, London, S.W.7.

${ }^{1}$ Wells, A., Nature, 194, 274 (1962).

${ }^{2}$ Graf, D. L., and Goldsmith, J. R., J. Geol., 64, 173 (1956).

\section{The Cabot and Great Glen Faults}

IN his recent contribution to this journal, Prof. Tuzo Wilson $^{1}$ describes the Cabot fault in the eastern coastal region of North America and compares it with the Great Glen fault which bisects the Scottish Highlands from the Firth of Lorne to the Moray Firth. He finds that trans. current movements on the line of the Cabot fault occurred during an interval extending from late Devonian to early Carboniferous times, and cites Kennedy's ${ }^{2}$ similar findings for the age of movements on the Great Glen fault as additional evidence of the close similarity of the two faults.
I have been engaged in a detailed investigation of the history of movements on the Great Glen fault, and have reached conclusions which are relevant to the question of the equivalence and possible former continuity of the Cabot and Great Glen faults. I have found conchusive evidence that while a sinistral transcurrent movement of the type recognized by Kennedy ${ }^{2}$ postdates the emplacement of the Morvern-Strontian and Foyers "Newer" Granite" complex, this movement was completed prior to the deposition of the Middle Old Red Sandstone in the area about Loch Ness and the Moray Firth. The presence of sediments of undoubted Middle Old Red Sandstone lithology $y^{3}$ among the sheared rocks of the fault-zone has resulted from further and distinctive transcurrent movements, of somewhat smaller magnitude than those of early Old Red age, which occurred in Tertiary times. These? latcr movements, which were dextral in sense, are chiefly recognizable because they have caused the dislocation of the Skye Tertiary dyke swarm at the line of the Great Glen fault. Prior to these movements, the major outcrops of the Middle Old Red Sandstone astride of the fault showed a detailed correspondence, as regards both geometry and lithology, such as is not apparent at the present day.

The dating of the major sinistral movement on the Great Glen fault is thus more narrowly defined and is earlier than the age interval found by Kennedy ${ }^{2}$ for the same dislocation. The comparability of this fault with the Cabot fault is therefore much less close than is claimed hy Wilson ${ }^{1}$.

Norman Holgate

Department, of Geology,
University of Glasgow.

${ }^{1}$ Wilson, T., Nature, 195, 185 (1962).

¿ Kennedy, W. Q., Quart. J. Geol. Soe. Lond., 102, 41 (1946).

"Eyles. V. A., and MacGregor, A. G., Geol. Mag., 89, 426 (1952).

THE new information provided about the Great Glen fault by N. Holgate is naturally welcome. I am grateful to him for pointing out its possible bearing on my suggestion $^{1}$ that the Great Glen and Cabot faults might have been two ends of the same fault, if Europe and North America had been joined together at the time of the formation of these faults, and if the continents had afterwards moved apart. Granted that Holgate's views are correct, there are still at least three points to be settled before they can be held to have invalidated my suggestion, although they may have modified it.

First, if the supposed date of faulting can be changed in an area so well studied as is most of Scotland, so can the age of the Cabot fault. I hinted in my paper at the conflict in the views which have been published about the age of faulting in Massachusetts and Rhode Island. If there appears to be less conflict in northern Newfoundland, it is because the areas of fossiliferous rocks are small and they have been little studied. D. M. Baird and officers of the Geological Survey of Canada have been so kind as to confirm in conversation that the age of the Cabot fault is neither firmly nor precisely established.

Secondly, the argument has been made more complex by R. Dearnley's description ${ }^{2}$ of the Minch fault between the Outer Hebrides and the mainland of Scotland. It is said to be similar in age and displacement to the Great Glen fault, but it is not precisely dated since "the available evidence, though fragmentary and inconclusive, suggests that the fault-movement occurred probably after the intrusion of the Lower Old Red Sandstone lamprophyres and almost certainly before the intrusion of tho (supposedly Permian) camptonites"'. Dearnley regards the Great Glen, Minch and other minor faults as members of the same fault system.

Thirdly, displacements of tens of miles on fault zones hundreds of miles long must have been spread over con- 